\title{
情報理論的クラスタリングによる異常值クラスタ の検出
}

\section{Detecting Clusters of Outliers with Information Theoretic Clustering}

\author{
安藤 晋群馬大学大学院工学研究科 \\ Graduate School of Engineering, Gunma University \\ ando@cs.gunma-u.ac.jp \\ 鈴木 英之進九州大学大学院システム情報科学研究院 \\ Einoshin Suzuki Graduate School of Information Science and Electrical Engineering, Kyushu University \\ suzuki@i.kyushu-u.ac.jp
}

keywords: Information Bottleneck, information theoretic clustering, outlier detection, minority detection

\begin{abstract}
Summary
Identifying atypical objects is one of the classic tasks in machine learning. Recent works, e.g., Oneclass Clustering and Minority Detection, have explored the task further to identify clusters of atypical objects which strongly contrast from the rest of the dataset. In such problems, avoiding false positive detection is an important yet significantly difficult issue. In this paper, we propose an information theoretic clustering which aims to compactly represent the global and local structures of the dataset and identify atypical clusters in terms of information geometric distance. The former objective contributes to reducing the number of false positive detections. Its formalization further yields a unifying view of the classic outlier detection and the novel tasks. We present a scalable algorithm for detecting multiple clusters of atypical objects without a pre-defined number of clusters. The algorithm is evaluated as an unsupervised two-class classification using simulated datasets and a text classification benchmark.
\end{abstract}

\section{1.はじめに}

データ集合中の特異事例は知識発見のための重要な手 掛りであり，光の検出は機械学習における基本的な問題の 一つである. 実用的にもデータマイニングの分野で異常 值検出や一クラス分類問題への取組みが多くの成果を上 げている [Hodge 04] . 近年さらに , 典型事例と重複する ような特異事例のクラスタ検出を扱う一クラスクラスタ リング (OCC)[Crammer 04]や Bregman Bubble クラ スタリング(BBC)[Gupta 06] , マイノリティ検出 [Ando 06, 安藤 07$]$ 等の研究がある.これらの手法は全体と異な る分布やクラスタ化傾向を持つ部分集合を抽出する問題 に取組み，遺伝子発現，テキス卜，画像等のベンチマー クでの有効性を示した . 近年の情報爆発により，観測事 例中で知識の構築に必要な関連事例は希薄化し，把握が より困難となっている．これに対し，上の取組みは知識 の要素となりうる事例を抽出する手段として期待される .

本稿ではデータ集合の大部分を妥当に説明する確率分 布が得られることを前提とし，弚の分布に従う事例を典 型事例と考える．また，典型事例とは大きく異なる生成 モデルにより説明される部分集合を特異事例のクラスタ とみなす．実用的な問題では特異事例の存在は所与では
なく，弚のクラスタが存在しない場合についての考慮を 要する.データ集合が典型事例のみで構成される場合に も，乥の部分集合が特異事例の生成モデルや内部平均距 離などの基準に適合し, クラスタとみなせてしまう場合 が多い. 通常のクラスタリングでは事前に指定した数の クラスタを決定するため，このような部分集合が悪局所 解となり擬陽性クラスタとして検出されやすい. 特異事 例が存在する場合にもこのような悪局所解が擬陽性検出 の原因となる . 擬陽性検出の抑制は重要な問題だが , こ のような悪局所解への収束を回避・判別することは困難 で, 上述の OCC, BBC でも解決されていない .

本研究ではデータ圧縮の枠組みに基づいて特異事例の クラスタ検出に取組む. 確率的情報源の圧縮・符号化に おける一つの中心的な問題がレート歪み理論である .こ れは符号化によって生じる “歪み”を抑えつつ, 圧縮率の 高い符号化を求める問題である. 符号化をクラスタへの 割当てとみなすと, 歪みの抑制はクラスタ内類似度の増 大 , 圧縮率の増大はより簡潔なクラスタリングを促すこ とに相当し，光れらを目的とするクラスタリングが定義 される.この枠組みを利用したクラスタリング手法は情 報理論的クラスタリング [Dhillon 03] とも呼ばれ，情報 ボトルネック (IB) 法 [Tishby 00] や Bregman クラスタ 
リング [Banerjee 05] 等に代表される．IB 法は基準情報 を持つ変数を利用するクラスタリング手法で, 多くの理 論的成果 [Chechik 05, Elidan 05, Slonim 06]や，実応 用 [Gao 07, Gordon 03, Hsu 06] がある . 圧縮率の増大 はクラスタリングにおいてはクラスタ変数の持つ情報量 の減少に当たる.典型事例と特異事例のクラスタから構 成されるデータ集合では，後者が小さいほどこの情報量 は減少する．われわれはこれを正規化に利用することで 擬陽性クラスタを縮退させ，擬陽性検出の抑制を目指す． 本研究では観測值のラベルに相当する变数をクラスタ リングする問題を扱う . コスト関数には共に相互情報量 で表されるクラスタ変数の持つ情報量とクラスタ間の情 報幾何的距離の線形和を用いる . 後者は検出されるクラ スタを情報幾何的な遠さの意味で特異なクラスタとする 以下ではこの問題をマイノリティクラスタリングと呼び， 検出されるクラスタを異常値クラスタと呼ぶ .

マイノリティクラスタリングでは異常值をクラスタと して検出するため光の統計量を知識発見に利用できる また，弚の定式化に基づき外れ值検出，OCC，マイノリ ティ検出等の問題について統一的に解釈することができ る. 本稿ではコスト関数の比較からこれらの問題がマイ ノリティクラスタリングの特殊ケースであることを示す . さらに, マイノリティクラスタリングのコスト関数は異 常值クラスタの分布が局所的であるという前提の下でク ラスタ毎の寄与に分割され，弚れ奖れが個別に繰返しア ルゴリズムによって局所最小解に収束する . われわれは これを連続的に実行することでクラスタ数を事前に指定 せず発見的に複数のクラスタを検出する手順を示す . こ のアルゴリズムは OCC,BBC の問題であった擬陽性検出 を抑制し，高い適合率で異常值クラスタを検出する。

以下に本稿の構成を示す. 2 章に情報理論の基本的な 定義を示す. 3 章, 4 章ではマイノリティクラスタリング の定式化とコスト関数の導出を行う. 5 章ではマイノリ ティクラスタリングの定式化に基づく従来手法の統一的 な解釈と考察を述べる. 6 章ではコス卜関数の最小化ア ルゴリズムを示す .7 章では人工データとテキスト分類 ベンチマークを用いて提案手法の実験的な比較検証を行 う.8 章で本研究の貢献を整理し，結論を述べる.

\section{2. 基 本 定 義}

以下に本稿で用いる情報理論の基本定義を示す . $X$ を 独立かつ同一の分布に従う変数とし, 弚の観測值を $\mathcal{X}=$ $\left\{x_{i}\right\}_{i=1}^{n}$ とする. また， $Y$ を有限集合 $\mathcal{Y}=\left\{y_{i}\right\}_{i=1}^{k}(k<n)$ の值をとる変数とし, $\mathcal{Y}$ の各要素がークラスタに対応す るものとする.クラスタ $y_{i}$ に関する条件付確率を $p\left(x \mid y_{i}\right)$ としたとき，データ $x$ の周辺確率は次式で与えられる .

$$
p(x)=\sum_{i=1}^{k} p\left(y_{i}\right) p\left(x \mid y_{i}\right)
$$

Kullback-Leibler(KL) ダイバージェンスは，確率分布 間の情報幾何的な尺度として広く用いられている.二つ の分布 $q_{1}(x), q_{2}(x)$ に対して下式で定義される.

$$
K L\left(q_{1}, q_{2}\right)=\sum_{x \in \mathcal{X}} q_{1}(x) \log \frac{q_{1}(x)}{q_{2}(x)}
$$

変数 $X$ と $Y$ の相互情報量は次のように与えられる.

$$
\begin{aligned}
I(Y ; X) & =\sum_{y \in \mathcal{Y}} \sum_{x \in \mathcal{X}} p(x, y) \log \frac{p(x, y)}{p(x) p(y)} \\
& =\sum_{y \in \mathcal{Y}} p(y) \sum_{x \in \mathcal{X}} p(x \mid y) \log \frac{p(x \mid y)}{p(x)} \\
& =\langle K L(p(x \mid y), p(x))\rangle_{Y}
\end{aligned}
$$

ただし $\langle\cdot\rangle_{Y}$ は $Y$ 上の期待値を表す.$p(x \mid y)$ はクラスタ $y$ に関する条件付確率であり， $K L(p(x \mid y), p(x))$ はデー 夕集合全体から見たクラスタの特異さを表す . (4) から $I(Y ; X)$ は光のクラスタの間での期待值とみなせる .

$I(Y ; X)$ はまた , エントロピー $H(Y)$ と $Y$ の $X$ に対 する条件付エントロピー $H(Y \mid X)$ と次の関係を持つ .

$$
I(Y ; X)=H(X)-H(Y \mid X)
$$

ただし， $H(Y), H(Y \mid X)$ は下式で与えられる .

$$
\begin{aligned}
H(Y) & =\sum_{y \in \mathcal{Y}} p(y) \log p(y) \\
H(Y \mid X) & =\sum_{x \in \mathcal{X}} p(x) \sum_{y \in \mathcal{Y}} p(y \mid x) \log p(y \mid x)
\end{aligned}
$$

\section{3. 情報理論的クラスタリング}

\section{$3 \cdot 1$ 情報ボトルネック法}

本節ではレート歪み理論を基礎とする学習原理である 情報ボトルネック (IB) 法 [Tishby 00] の概要を述べる .

$X$ を観測変数とし， $Y$ を各クラスタに対応する有限個 の值をとる変数とする.クラスタリングは $X$ の $Y$ への 確率的割当て $p(Y \mid X)$ を決定する問題と定義される． $Y$ を $X$ を圧縮した符号と考えると，圧縮率 (レート)が相 互情報量 $I(Y ; X)$ により定量化される.

IB 法はタスクに関連する情報を持つ変数 $Z$ と $X$ の同 時確率分布 $p(X, Z)$ を入力とする. $Z$ は例えば一部のク ラスや少数のサンプルに関するラベルと考えられる．実 用的には完全なラベル付きデータが得難い場合にも，こ のような部分的なラベルを利用できることが多い .

$Z$ を基にクラスタリングの悪さ (歪み) を $-I(Y ; Z)$ と定量化する.レート $I(Y ; X)$ と歪み $-I(Y ; Z)$ は共に $p(Y \mid X)$ の汎関数であり，後者に関する上限が与えられ たとき，変分法により光の制約の下で前者を最小化する $p(Y \mid X)$ が求まる. IB 法は次のような二つの相互情報量 のラグランジアンを最小化する問題として定式化される .

$$
\min _{p(Y \mid X)} I(Y ; X)-\beta I(Y ; Z)
$$


ただし，一般的なクラスタリング問題では歪みの上限は 与えられないため，あるトレードオフ $\beta$ の下で(6) を最 小化するクラスタリングを求める .

(6) の第一項は,クラスタ変数が観測変数に対して持 つ情報量であり，情報量基準や最小記述長原理のような 学習結果の複雑さに対する正規化項と解釈できる．第二 項はクラスタ変数と基準変数間の歪みを定量化する . (6) において $Z$ は圧縮による $X$ に関する情報の損失を抑制 する役割を果たすことからボトルネック変数と呼ばれる .

変数間の関係は $X$ が $Z$ の， $Y$ が $X$ の関数とみなさ れ, $Z \rightarrow X \rightarrow Y$ というマルコフ過程で表される.$X$ が 所与のとき $Z$ と $Y$ は互いに独立であるため常に不等式 $I(Z ; Y)<I(Z ; X)$ が成立する.これを用いて最小化問 題(6)の凸性や解析的な解が得られる [Tishby 00] .

\section{$3 \cdot 2$ 情報理論的クラスタリングの定式化}

IB 法はクラスタリング問題をクラスタ変数 $Y$ のレー 卜 $I(Y ; X)$ と教師情報 $Z$ について持つ情報量 $I(Y ; Z)$ からなるコスト関数の最小化問題として定式化する . こ れに対し，以下では新たに教師情報が無い場合について の情報理論的クラスタリングを定式化する .

$X$ の観測值 $\mathcal{X}=\left\{x_{1}, \ldots, x_{n}\right\}$ を別のクラスタ変数に よって記述することを考える. $x_{i}$ が文書を表す単語頻度 ベクトルとすれば，これは文書をカテゴリにクラスタリ ングする問題に当たる．まず， $\mathcal{T}=\{1,2, \ldots, n\}$ の值を とる変数 $T$ に対し $\mathcal{X}$ を 1 対 1 で割当てることを考える. これは一文書を一カテゴリとする極めてて長なカテゴリ 化とみなせる .さらに $T$ を $\mathcal{Y}=\left\{y_{1}, \ldots, y_{k}\right\} \quad(k<n)$ の值をとるクラスタ変数 $Y$ に割当てる問題を考える.$Y$ は $T$ をより簡潔にまとめた大カテゴリに相当する .この ときレートは $I(Y ; T)$ で与えられる.続いて, 歪みとし て $Y$ か観測変数について持つ情報量から $-I(Y ; X)$ を 考える. $x_{i}$ が単語頻度ならばカテゴリ $Y$ が単語に関し て多くの情報を保持するほどこの值は小さくなる．

以上より Tのクラスタリングを次のようなレート歪み 問題の形式の最小化問題として定式化する.

$$
\min _{p(Y \mid T)} I(Y ; T)-\beta I(Y ; X)
$$

ただし, 決定変数は $p(Y \mid T)$, 入力は $p(X, T)$ である . $p(X, T)=p(T) p(X \mid T)$ は $|\mathcal{X}|=|\mathcal{T}|=n$ より各デー タが個別の情報源から生成される $n$ 混合モデルの記述と みなせる . (7) ではこれを入力として $p(Y \mid T)$ を決定し， そこからより簡潔なモデルの記述 $p(X \mid Y)$ を得る.(7)の 第一項はこの記述の簡潔さを促す正規化項となる .一方， 第二項は観測値について維持される情報量，すなわちク ラスタ間のダイバージェンスの増大を促す .

(7) は (6) との比較から $X$ をボトルネック変数とする IB 法と解釈できる . (7) では $X$ が $Y$ の持つ情報の損失 を抑制する変数となる.ただし, IB 法が $X, Z$ を所与と
するのに対し，(7) では $X$ のみが所与で教師情報を用い ない. 変数の関係は $Y$ が $T$ の,$T$ が $X$ の関数とみなせ るため， $X \rightarrow T \rightarrow Y$ というマルコフ過程で表される .

\section{4. マイノリティクラスタリング}

マイノリティクラスタリングは大域的に分布する典型 事例と局所的に分布する特異事例が混在するデータ集合 をクラスタリングする問題である．以下では, 前節に示 した情報理論的クラスタリングに異常值クラスタの局所 性に関する制約を導入することでこの問題を定式化する． $\tau \in \mathcal{T}$ を観測值 $x_{\tau}$ に対応するクラス, $y_{1}$ を典型的事 例 $, y_{2}, \ldots, y_{k}$ を異常值クラスタに対応する值とする .さ

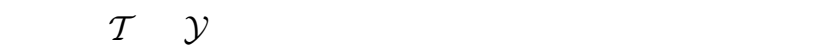
ち条件付確率の值が $p\left(y_{i} \mid \tau\right) \in\{0,1\}$ に限定されるもの とする .なお, 決定的, 確率的割当てがクラスタリング に与える影響については [Kearns 99] が詳しい.このと き $T$ が与えられると $Y$ に関するあいまいさはなくなる ため $H(Y \mid T)=0$ である $. I(Y ; T)=H(Y)-H(Y \mid T)$ から (7) のコスト関数は次式 $F$ のように書換えられる.

$$
F=H(Y)-\beta I(Y ; X)
$$

さらにクラスか対応する事例についても次のような制 約をおく. 各事例が属する異常值クラスタはただーつと 考え, 他の異常值クラスタとの同時確率は無視できるも のとする . このとき異常値クラスタは相互に重複や包含 関係を持たない局所的な分布とみなせる．ただし，典型 事例の分布はデータ集合全体を覆う大域的なものと考え， 異常値クラスタとの重複を考慮する。

上の制約はクラスタ $y_{i}$ に割当てられた $\tau$ に対応する事 例 $x_{\tau}$ の他の異常值クラスタに対する条件付確率が 0 に 限定されることとして，次のような式で表される .

$$
p\left(x_{\tau} \mid y_{i}\right)=0 \forall i, \tau \text { s.t. } p\left(y_{i} \mid \tau\right)=0, i \neq 1
$$

\section{$4 \cdot 1$ 歪み の 分 離}

(9) の制約の下ではコスト関数(7) に対するクラスタ毎 の寄与を分離することができる .

$I(Y ; X)$ に対するクラスタ $y_{i}$ の寄与 $\Phi_{i}$ は

$$
\Phi_{i}=p\left(y_{i}\right) \sum_{x \in \mathcal{X}} p\left(x \mid y_{i}\right) \log \frac{p\left(x \mid y_{i}\right)}{p(x)}
$$

と表され,$\sum_{i=1}^{k} \Phi_{i}=I(Y ; X)$ である .ここで，

$$
\mathcal{X}_{i}=\left\{x_{\tau}: p\left(y_{i} \mid \tau\right)=1\right\}
$$

となる部分集合 $\mathcal{X}_{i}$ を考えると,$(9)$ から $x_{\tau} \notin \mathcal{X}_{i}$ となる $i, \tau$ について $p\left(x_{\tau} \mid y_{i}\right)=0$ であるため異常値クラスタの 寄与 $\Phi_{j}(j \in\{2, \ldots, k\})$ は下式で与えられる.

$$
\Phi_{j}=p\left(y_{i}\right) \sum_{x \in \mathcal{X}_{i}} p\left(x \mid y_{i}\right) \log \frac{p\left(x \mid y_{i}\right)}{p(x)}
$$


一方 , 典型事例の寄与分 $\Phi_{1}$ も $(11)$ と同樣の式で表さ れ, さらに各 $\mathcal{X}_{i}(i=1, \ldots, k)$ 毎の和に分離できる . こ れらを $\Phi_{1}\left(\mathcal{X}_{i}\right)$ と表すと

$$
\Phi_{1}\left(\mathcal{X}_{i}\right)=\sum_{x \in \mathcal{X}_{i}} p\left(x, y_{1}\right) \log \frac{p\left(x \mid y_{1}\right)}{p(x)}
$$

であり， $\Phi_{1}=\sum_{i=1}^{k} \Phi_{1}\left(\mathcal{X}_{i}\right)$ である.

ここで, 周辺分布 $p(x)$ を $(1)$ から次のように書換える.

$$
p(x)=p\left(y_{1}\right) p\left(x \mid y_{1}\right)+\sum_{i=2}^{k} p\left(y_{i}\right) p\left(x \mid y_{i}\right)
$$

上式の $\sum$ 以下は $(9)$ より $x \in \mathcal{X}_{1}$ に関しては無視でき るため， $\Phi_{1}\left(\mathcal{X}_{1}\right)$ は次のように書換えられる.

$$
\begin{aligned}
\Phi_{1}\left(\mathcal{X}_{1}\right) & =\sum_{x \in \mathcal{X}_{1}} p\left(x, y_{1}\right) \log \frac{p\left(x \mid y_{1}\right)}{p\left(y_{1}\right) p\left(x \mid y_{1}\right)} \\
& =\sum_{x \in \mathcal{X}_{1}} p\left(x, y_{1}\right) \log \frac{1}{p\left(y_{1}\right)}
\end{aligned}
$$

(11), (12), (13) より $I(Y ; X)=\sum_{i=1}^{k} \Phi_{i}$ は

$$
\begin{gathered}
\sum_{i=2}^{k} \sum_{x \in \mathcal{X}_{i}}\left\{p\left(x, y_{1}\right) \log \frac{p\left(x \mid y_{1}\right)}{p(x)}+p\left(x, y_{i}\right) \log \frac{p\left(x \mid y_{i}\right)}{p(x)}\right\} \\
+\sum_{x \in \mathcal{X}_{1}} p\left(x, y_{1}\right) \log \frac{1}{p\left(y_{1}\right)}
\end{gathered}
$$

と書換えられる.

\section{$4 \cdot 2$ 記述コストの分離}

(8) ではクラスタ变数の持つ情報量が $H(Y)=\sum_{i=1}^{k}$ $p\left(y_{i}\right) \log \frac{1}{p\left(y_{i}\right)}$ で表される.ここで周辺分布 $p\left(y_{i}\right)$ が

$$
p\left(y_{i}\right)=\sum_{x \in \mathcal{X}} p(x) p\left(y_{i} \mid x\right)
$$

を満たすことから $H(Y)$ は次のように書換えられる .

$$
\sum_{i=1}^{k} \sum_{x \in \mathcal{X}} p\left(x, y_{i}\right) \log \frac{1}{p\left(y_{i}\right)}
$$

(15) は総和の順序を交換することで $\mathcal{X}_{i}$ 毎の寄与分に分 離できる.以下ではこれを $\left(\mathcal{X}_{i}\right)$ と表す . $(9)$ より $x \in \mathcal{X}_{1}$ に関して $p\left(x, y_{i}\right)$ を無視できるため, $\Pi\left(\mathcal{X}_{1}\right)$ は

$$
\Pi\left(\mathcal{X}_{1}\right)=\sum_{x \in \mathcal{X}_{1}} p\left(x, y_{1}\right) \log \frac{1}{p\left(y_{1}\right)}
$$

と書ける .同樣に $\mathcal{X}_{j}(j \in\{2, \ldots, k\})$ につては $p\left(x, y_{1}\right)$, $p\left(x, y_{i}\right)$ 以外は無視できるため $\Pi\left(\mathcal{X}_{j}\right)$ は次式で表される .

$\Pi\left(\mathcal{X}_{j}\right)=\sum_{x \in \mathcal{X}_{j}}\left\{p\left(x, y_{1}\right) \log \frac{1}{p\left(y_{1}\right)}+p\left(x, y_{j}\right) \log \frac{1}{p\left(y_{j}\right)}\right\}$
以上より $H(Y)=\sum_{i=1}^{k} \Pi\left(\mathcal{X}_{i}\right)$ は次式で表される .

$$
\begin{gathered}
\sum_{i=2}^{k} \sum_{x \in \mathcal{X}_{i}}\left\{p\left(x, y_{1}\right) \log \frac{1}{p\left(y_{1}\right)}+p\left(x, y_{i}\right) \log \frac{1}{p\left(y_{i}\right)}\right\} \\
+\sum_{x \in X_{1}} p\left(x, y_{1}\right) \log \frac{1}{p\left(y_{1}\right)}
\end{gathered}
$$

\section{$4 \cdot 3$ コスト 関数の分離}

(14) と (16) を(8) に代入し， $\beta=1$ とすると $\mathcal{X}_{1}$ に関 する総和が相殺され, クラスタ毎に分離した形のコスト 関数 $F_{L}$ を得る.

$$
\begin{aligned}
F_{L}= & -\sum_{i=2}^{k} \sum_{x \in \mathcal{X}_{i}}\left\{p\left(x, y_{1}\right) \log \frac{p\left(y_{1}\right) p\left(x \mid y_{1}\right)}{p(x)}\right. \\
& \left.+p\left(x, y_{i}\right) \log \frac{p\left(y_{i}\right) p\left(x \mid y_{i}\right)}{p(x)}\right\}
\end{aligned}
$$

$(17) \sum$ 内の二項は光れ光れ $\mathcal{X}_{i}$ 上での $p\left(x, y_{1}\right)$ と $p(x)$, $p\left(x, y_{i}\right)$ と $p(x)$ の KL ダイバージェンスである.いずれ も異常值クラスタの分布が $p(x)$ から遠いほど , すなわ ち非典型的であるほど増大し，同時に $F_{L}$ は減少する .

本節では $y_{1}$ のみが典型事例に対応するとしたが , 典型 事例の分布が複数ある場合でもコス卜関数は異常值クラ スタ毎の総和として表される. 弚の場合， $p\left(x \mid y_{1}\right)$ を混 合分布と考えることで(17) と同樣の形式が得られる .

$\beta=1$ は情報理論的クラスタリングにおける典型的な 值であり [Banerjee 04, 安藤 07] , クラスタの密度と局所 最小解の変分に関する条件から導出される. 7 章に示す 実験では全てこの值を用いる .この手法の $\beta$ に対する依 存については実験結果を踏まえ 8 章に述べる．

\section{5. 従来手法との関連}

本節ではコスト関数の比較を基に複数の従来手法とマ イノリティクラスタリングについて統一的な解釈を示す .

\section{$5 \cdot 1$ マイノリティ検出}

マイノリティ検出 (MD) 法 [Ando 06] はデータ集合中 のマイノリティ, すなわち少数派のクラスタを多数派で ある典型事例との分布の差異に注目して検出する手法で ある . この手法では観測值 $\mathcal{X}=\left\{x_{j}\right\}_{j=1}^{n}$ を多数派クラス $y_{1}$ と少数派クラス $y_{2}$ のいずれかに割当てる問題を扱い, 解として次のような決定的な割当てを考える.

$$
p\left(y_{i} \mid x_{j}\right)=\delta_{h i}, h=\underset{h \in\{1,2\}}{\arg \max } p\left(x_{j}, y_{h}\right)
$$

$\delta$ はクロネッカーのデルタを表す . さらに , 少数派クラス に関する $p\left(y_{2}\right) \ll 1$ という前提から次の近似を用いる.

$$
\begin{aligned}
p(x) & =p\left(y_{1}\right) p\left(x \mid y_{1}\right)+p\left(y_{2}\right) p\left(x \mid y_{2}\right) \\
& \approx p\left(y_{1}\right) p\left(x \mid y_{1}\right)=p\left(x, y_{1}\right)
\end{aligned}
$$


ぞの上で次のコスト関数を最小化する割当てを求める.

$$
F_{M D}=\sum_{x \in \mathcal{X}_{2}} \log \frac{p\left(x ; \pi^{*}\right)}{p\left(y_{2}\right) p\left(x \mid y_{2}\right)}
$$

ここで, $\mathcal{X}_{2}$ は $\left\{x \in \mathcal{X}: p\left(y_{2} \mid x\right)=1\right\}$ となる少数派事例 集合を表す.$\pi$ は $p\left(x \mid y_{1}\right)$ のパラメータであり， $\pi^{*}$ は

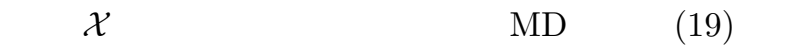
$p\left(x ; \pi^{*}\right)$ を $p(x)$ の近似として固定する .

(20) は $\log \frac{1}{p\left(y_{2}\right)}$ と $\log \frac{p\left(x \mid \pi^{*}\right)}{p\left(x \mid y_{2}\right)}$ に分けられ，光れ光れ 次のように解釈できる . 前者は少数派クラスタの持つ情 報量を定量化し,簡潔なクラスタリングほど減少する.後 者は多数派と少数派クラスタの分布間の情報幾何的距離 を表し, 少数派の特異性が高いほど減少する。

ここで, (17)について $k=2$ とした場合を $F_{L}^{2}$ とする .

$$
\begin{aligned}
F_{L}^{2}= & \sum_{x \in \mathcal{X}_{2}}\left\{p\left(x, y_{1}\right) \log \frac{p(x)}{p\left(y_{1}\right) p\left(x \mid y_{1}\right)}\right. \\
& \left.+p\left(x, y_{2}\right) \log \frac{p(x)}{p\left(y_{2}\right) p\left(x \mid y_{2}\right)}\right\}
\end{aligned}
$$

$F_{L}^{2}$ と $F_{M D}$ との比較から次の命題を得る.

命題 1. $M D$ 法はマイノリティクラスタリングにおいて (19) を仮定し， $k=2$ とした場合の特殊ケースであり，乥の とき $F_{L}^{2}$ と $F_{M D}$ の最小化は等価である .

証明.(19) の前提の下では $F_{L}^{2} の \sum$ 内の第一項は無視で きるため，第二項のみ考慮すればよい . (10)の定義から $\mathcal{X}_{2}$ は二つの式で同じ部分集合を指す．一方，各事例の割 当ては決定的であるため $x \in \mathcal{X}_{2}$ に関して $p\left(x, y_{2}\right)$ は同 一である.よって $p(x)$ を推定値 $p\left(x ; \pi^{*}\right)$ で置換えると $F_{L}^{2}$ と $F_{M D}$ は同じ形式となり同時に最小化される .

上の命題からマイノリティクラスタリングを基に MD 法は $k>2$ の場合に拡張することができ，弚のコスト関 数 $F_{M D}^{k}$ は次式で与えられる.

$$
F_{M D}^{k}=\sum_{i=1}^{k} \sum_{x \in \mathcal{X}_{i}} \log \frac{p\left(x ; \pi^{*}\right)}{p\left(y_{i}\right) p\left(x \mid y_{i}\right)}
$$

\section{$5 \cdot 2$ 外れ值検出とークラス分類}

ある事例についてデータ集合中の大部分の事例と同一 の分布から生成されたという仮説が棄却されるとき，光 の事例は外れ値とみなせる [Roth 06] . 产の決定関数は所 与の信頼度 $\alpha$ と生成モデルに基づく周辺確率 $p(x)$ から 定義される . 例えば正規分布に従う変数では中心からの マハラノビス距離がある閾値を越える值が外れ值となる．

一クラス分類 [Schölkopf 01] は外机值検出を二次計画 問題として定義し，サポートベクトルマシン (SVM)の 教師無し学習への応用であるークラス SVM によって解 く. [Schölkopf 01] はさらに,一クラス分類の一つとし て超球 (Ball) を用いた外れ值検出 (Ball 分類) 問題を示 した .これは $n$ 個の事例を超球によって分類する問題で
ある. 超球外の事例を外れ値とし, 内外の事例間のマー ジンが最大となるよう超球を決定する．ただし，外れ値

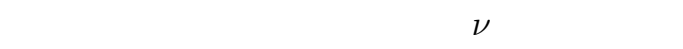

超球内の事例の中心を $\mu_{c}$ とすると, $\mu_{c}$ から $x$ までの 距離はカーネル関数 $\phi$ を用いて $\phi\left(x, \mu_{c}\right)$ と表される .こ こで, カーネル $\phi$ に固有な指数関数族の確率分布 $p_{\phi}$ が

$$
p_{\phi}\left(x, \mu_{c}\right)=Z(x) \exp \left(-\frac{1}{2} \phi\left(x, \mu_{c}\right)\right)
$$

と定義される．ただし， $Z$ は正規化項である． $p_{\phi}$ を用いると Ball 分類は次のコスト関数 $F_{\text {Ball }}$

$$
F_{\text {Ball }}=\sum_{i=1}^{\nu n} \log p_{\phi}\left(x_{i}, \mu_{c}\right)
$$

の最小化問題として表される .

(24) の最小化は外れ值検出の双対問題である .すなわ ち，あるデータ集合中で信頼度 $\alpha$ で外れ值となる事例の 割合には上限 $\nu_{\alpha}$ か存在し, $\nu=\nu_{\alpha}$ とした Ball 分類と信 頼度 $\alpha$ を用いた外れ值検出は同じ外れ值集合を出力する．

ここで, カーネル $\phi, \psi$ から定まる確率分布 $p_{\phi}, p_{\psi}$ を典 型事例と異常値クラスタの生成モデルとし, $p_{\psi}$ が

$$
p_{\psi}(x, x(i)) \approx 0, \forall x \in \mathcal{X} \backslash x(i)
$$

を満たす狭い分布となるよう $\psi$ を選ぶ .このとき異常値 クラスタは要素を一つだけ持つシングルトンクラスタと なる.これを踏まえ，Ball 分類について次の命題を得る. 命題 2. $F_{\text {Ball }}$ の最小化は $k=\nu n$ とし, (25) を満たす異 常值クラスタの生成モデルを用いた $M D$ 法と等しい .

証明.(25) より異常値クラスタは $\mathcal{X}_{i}=\{x(i)\}$ のみを要 素とする .この要素の $y_{i}$ に対する条件付確率は $(23)$ よ り, $p\left(x(i) \mid y_{i}\right)=p_{\psi}(x(i), x(i))$ と与えられ，これは全 てのクラスタと关の要素について同一である . 周辺分布 $p\left(y_{i}\right)$ についても同樣であるから $(22)$ の最小化で意味を 持つのは $p\left(x ; \pi^{*}\right)$ のみである. $\pi$ は多数派事例の分布パ ラメータであるから, 弚の平均 $\mu_{1}$ とカーネル $\phi$ によ $p(x ; \pi)=p_{\phi}\left(x, \mu_{1}\right)$ と表される.このとき $F_{M D}^{\nu n}$ と $F_{\text {Ball }}$ は同じ形をとり，これらの最小化は等価である .

\section{$5 \cdot 3$ 一クラスクラスタリング}

多くの実用的なデータ集合ではクラスタ化傾向を示さ ない事例が大部分を占めるが, 弚の中に密なクラスタを 構成する事例集合が存在するとき，乥れは知識発見の手掛 かりとなることが多い.ークラスクラスタリング $(\mathrm{OCC})$ は产のようなクラスタの抽出を目標とした手法で, 文書 や遺伝子発現量のベンチマークでの有効性が示されてい る [Crammer 04, Gupta 05] .

$\mathrm{OCC}$ は $s$ 個の事例を内包する最小半径の超球を求め る問題を扱うが, 任意の Bregman ダイバージェンスを距 離関数として扱えるためロジスティック関数や Pearson 
相関等の幅広い尺度を利用できる点が特長である．弚の コスト関数は $D_{\varphi}$ を Bregman ダイバージェンスの定義 を満たす距離関数， $\mu$ を超球の中心, $\mathcal{C}$ を $s$ 個の要素か らなるクラスタとするとき次式で定義される .

$$
F_{\mathrm{OC}=\sum_{x \in \mathcal{C}} D_{\varphi}\left(x, \mu_{\mathcal{C}}\right)}
$$

Bregman ダイバージェンス $D_{\varphi}$ からは固有の指数関数 分布 $p_{\varphi}$ が次のように定義される.

$$
p_{\varphi}(x ; \theta)=Z(x) \exp \left(-\beta D_{\varphi}\left(x, \mu_{\mathcal{C}}\right)\right)
$$

$\theta$ は $\varphi$ に固有な分布パラメータ, $Z$ は正規化関数を表す OCC と確率モデルに基づく手法の関係は $p_{\varphi}$ を用いて 次のように説明される . $Y$ を $\mathcal{Y}=\{0,1\}$ の值をとる変数 とする $y=1$ をクラスタに対応する值とし，条件付確 率 $p(x \mid y)$ を $p_{\varphi}(x ; \theta)$ で与える.一方, $y=0$ はクラスタ 化傾向を持たない事例集合に対応する值とし，兴の分布 は疎な一樣分布とする . このとき $p(y \mid x)$ の最尤推定

$$
\max _{p(y \mid x)} \sum_{y \in \mathcal{Y}} p(y) \sum_{x \in \mathcal{X}} \log p(x \mid y)
$$

と $F_{O C}$ の最小化は双対な問題となる [Gupta 06] .ただ し, OCC では $p(y \mid x) \in\{0,1\}$ となる決定的割当てのみ を考える .また , $p(x \mid 0)$ は一樣分布であるため尤度最大 化原理では決定されず，初期推定值に固定される .

OCCの多クラスタへの自然な拡張がBregman Bubble クラスタリング (BBC) [Gupta 06] である . 兴のコスト 関数 $F_{B B C}$ は $(28)$ を基に次式で与えられる.

$$
F_{B B C}=\sum_{y=1}^{k} \sum_{x \in \mathcal{C}_{y}} \log \frac{1}{p(x, y)}
$$

$\mathcal{C}_{y}=\{x \in \mathcal{X}: p(y \mid x)=1\}$ は各クラスタの要素を表す. 命題 3. $F_{B B C}$ の最小化はクラスタの要素数を $s$ 個に限 定し，かつ典型事例を一樣分布とした $M D$ 法に等しい．

証明. $p\left(x ; \pi^{*}\right)$ が $x \in \mathcal{X}$ 上で一樣であるとき $(22)$ の最小化 に関してこれを無視できる.さらに,$p(x, y)=p(x \mid y) p(y)$ より $F_{M D}^{k}$ は $F_{B B C}$ と同じ形式をとる .

\section{$5 \cdot 4$ 考 察}

[Crammer 04] らは Ball 分類と OCC のコスト関数の 解析を行い, 前者ではデー夕集合全体の大域的な特徵, 後 者ではクラスタの局所的な特徵に基づいて特異事例が決定 されることを示した . 両手法の対照性はコスト関数 $(24)$ ， (29)の形式からも明らかである .

$$
\begin{aligned}
& \text { ここでマイノリティ検出のコスト関数 }(22) \text { を } \\
& \qquad \sum_{i=1}^{k} \sum_{x \in \mathcal{X}_{i}}\left\{\log p(x ; \pi)+\log \frac{1}{p\left(x, y_{i}\right)}\right\}
\end{aligned}
$$

と書換えると, $F_{M D}^{k}$ が上述の二手法のコスト関数を結 合する形をとることが分かる.ここから命題 2,3 につ いてさらに次のような定性的な解釈が得られる．異常值 クラスタをシングルトンに限定したとき，KL ダイバー ジェンスはカーネル関数で表される距離に還元し, 谷の 定義は外れ值と一致する.一方, 背景雑音が一樣に分布 するとき，光の KL ダイバージェンスへの寄与は無視で きるため異常值クラスタは OCC, BBC のクラスタに等 しい .ただし，MD 法は BBC とは異なり，背景が密ま たは非一樣な分布，ガウス分布等の場合も扱える . (30) から，MD 法は外れ值と密なクラスタという二つの対照 的な概念を同時に一般化する手法とみなせる．

$\mathrm{MD}$ 法や OCC は典型事例の分布を固定して異常値ク ラスタを推定する . 典型事例と異常値クラスタが重複し， 後者の割合が非常に小さい場合, 兴のパラメータ決定が 全体に与える影響は小さく，これは妥当と考えられる．

\section{6. アルゴリズム}

\section{$6 \cdot 1$ マイノリティ検出 $(\mathrm{MD})$ アルゴリズム}

$\mathrm{IB}$ 法は周辺分布 $p(y \mid x), p(z \mid y)$ と条件付確率 $p(y)$ を 繰返し更新し, コスト関数の局所最小解に収束するアル ゴリズムを持つ [Tishby 00] . 以下ではマイノリティクラ スタリングの典型事例の分布を固定した場合，すなわち， $\mathrm{MD}$ 法のコスト関数 $(22)$ について同樣の枠組みにより局 所最小化する手順を示す.

まず， $(22)$ へのクラスタ $i$ の寄与 $L_{i}$ を最小化する手 順を示す $. F_{L}=\sum_{i} L_{i}$ であり， $L_{i}$ は下式で与えられる .

$$
L_{i}\left(\theta_{i}, \mathcal{X}_{i}\right)=\sum_{x \in \mathcal{X}_{i}}\left\{\log \frac{p\left(x ; \pi^{*}\right)}{p\left(x ; \theta_{i}\right)}+\log \frac{1}{p\left(y_{i}\right)}\right\}
$$

この問題における決定変数は条件付確率 $p(y \mid \tau)$ であ り，他の分布は乥こからべイズの定理等に基づき計算で きる. 弚こで, $p(y \mid \tau), p(y), p(x \mid y)$ の三つの分布につ いて，他の二つを固定したとき $L_{i}$ を最小とする值を求 め，弚の繰返しにより $L_{i}$ を収束させることを考える．

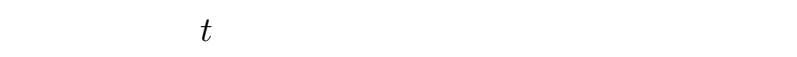

$$
\begin{aligned}
p_{t+1}\left(y_{i} \mid \tau\right) & =\delta_{\tau h}, h=\underset{\tau \in \mathcal{T}}{\arg \max } p_{t}\left(x_{\tau}, y_{i}\right) \\
p_{t+1}(y) & =\sum_{\tau \in \mathcal{T}} p_{t+1}(y \mid \tau) p(\tau) \\
p_{t+1}(x \mid y) & =p\left(x, \theta^{*}\right)
\end{aligned}
$$

ただし,$\theta^{*}=\underset{\theta}{\arg \max } \sum_{x \in \mathcal{X}_{i}} \log p(x \mid \theta)$ である.また , $\mathcal{X}_{i}$ は $p_{t}\left(y_{i} \mid \tau\right)$ から (10) に従って決定される .

命題 4. (32)-(34) を繰返し更新するアルゴリズムは $p(Y \mid T)$ を決定変数とする $(31)$ の局所最小解に収束する.

証明. $p\left(x \mid y_{i}\right)<1$ と $0<p\left(x, \pi^{*}\right)$ より(31) の $\sum$ 内の第 一項は下界を持つ.また , $p\left(y_{i}\right)<1$ より第二項も非零で 
INPUT: 観測値 $\mathcal{X}=\left\{x_{j}\right\}_{j=1}^{n}$, 最尤推定值 $\pi^{*}$, 初期割 当て $p_{0}\left(y_{i} \mid \mathcal{T}\right)$

OUTPUT: $\theta, p(y \mid \mathcal{T})$

METHOD:

初期化 $\theta=\underset{\theta}{\arg \max } \sum_{\mathcal{X}_{i}} \log p(x \mid \theta)$

repeat

for $x_{\tau} \in \mathcal{X}_{i}$ do

if $p\left(x_{\tau} \mid \theta\right)<p\left(x_{\tau} \mid \pi^{*}\right)$ then $p\left(y_{i} \mid \tau\right)=0$

end if

end for

$$
\begin{aligned}
& p\left(y_{i}\right) \leftarrow \frac{1}{n} \sum_{x_{\tau} \in \mathcal{X}_{i}} p\left(y_{i} \mid \tau\right) \\
& \theta \leftarrow \underset{\theta}{\arg \max } \sum_{x \in \mathcal{X}_{i}} \log p(x \mid \theta)
\end{aligned}
$$

until $F_{M D}$ converges

return $\theta,\left\{p\left(y_{i} \mid \tau\right)\right\}_{\tau=1}^{n}$

図 1 マイノリティ検出 $(\mathrm{MD})$ アルゴリズム

あるため $L_{i}$ 全体でも下界を持つ.よって (32), (33), (34) が弚れ午れ $L_{i}$ を単調に減少させることを示せばよい .

$p(y \mid \tau)$ の更新は同時に(10) で定義される $\mathcal{X}_{i}$ を更新す る . (32) は尤度比 $\log \frac{p\left(x, \pi^{*}\right)}{p\left(x \mid y_{i}\right)}$ が正となる事例を $\mathcal{X}_{i}$ から 除くように更新するため, $L_{i}$ は減少する.

$\mathcal{X}_{i}$ から要素が除かれると, 全ての観測事例は同一で $p(\tau)=\frac{1}{|T|}$ であるため(33)によって $\log \frac{1}{p(y)}$ が減少し， 同時に $L_{i}$ も減少する.

$(31)$ より, $p_{t+1}(y)$ と $p\left(x, \pi^{*}\right)$ がともに固定されたと き $L_{i}$ を最小化する $p_{t+1}(x \mid y)$ のパラメータは最尤推定 值 $\theta^{*}$ である.よって (34) の更新は $L_{i}$ を減少させる.

以上から, 各式の更新は $L_{i}$ は単調に減少させ, さらに $p(Y \mid \mathcal{T})$ の組合せは有限であるため(32)-(34) の有限の繰 返しによって $L_{i}$ は局所最小解に収束する.

图 1 に MD アルゴリズムの擬似コードを示す . $p_{0}\left(y_{i} \mid \mathcal{T}\right)$ は初期割当てを表し, 出力 $p\left(y_{i} \mid T\right)$ から異常値クラスタ が $\left\{x_{\tau}: p\left(y_{2} \mid \tau\right)=1\right\}$ と決定される . 図 1 の繰返し内で はクラスタの要素 $\mathcal{X}_{i}$ のみを計算で用いるため， $L_{i}$ は他 のクラスタとは独立に最小化することができる .

典型事例のみから構成される,すなわち全要素が $p\left(x, y_{1}\right)$ から生成されたクラスタ $\mathcal{X}_{i}$ は MD アルゴリズムにより 縮退する . ステップ $t$ において部分集合 $\mathcal{X}_{i}^{t}$ が, $\mathcal{X}_{i}^{t+1}=$ $\mathcal{X}_{i}^{t}-x^{\prime}$ に更新された場合を考えると， $x^{\prime}$ は典型事例で あるから弚れを除くことで $\theta_{i}$ と $\pi^{*}$ によって表される分 布間の距離は増大し, $\log \frac{p\left(x, \pi^{*}\right)}{p\left(x, \theta_{i}\right)}$ の期待値は減少する. また, クラスタの要素数が減ることから $\log \frac{1}{p\left(y_{i}\right)}$ が減少 し，あわせて $L_{i}$ も減少する.$x^{\prime}$ を除くことで $p\left(x ; \theta_{i}\right)$ の 分散は縮小し, より狭い分布となる $. p\left(x ; \theta_{i}\right)<p\left(x ; \pi^{*}\right)$ となる領域が拡大すると, 十分に密な $\mathcal{X} て ゙ は ~ \log \frac{p\left(x, \pi^{*}\right)}{p\left(x, \theta_{i}\right)}$ が負となる事例 $x^{\prime}$ が増加し, さらに $\mathcal{X}_{i}^{t+1}=\mathcal{X}_{i}^{t}-x^{\prime}$ と
INPUT: 観測值 $\mathcal{X}=\left\{\mathbf{x}_{i}\right\}_{i=1}^{n}$, 最尤パラメータ $\pi^{*}$, 最 大初期化回数 $t_{\max }$, 最小クラスタサイズ $s_{\min }$ OUTPUT: $p(\mathcal{Y} \mid \mathcal{T}), \Theta=\left\{\theta_{i}\right\}_{i=1}^{k}$ METHOD:

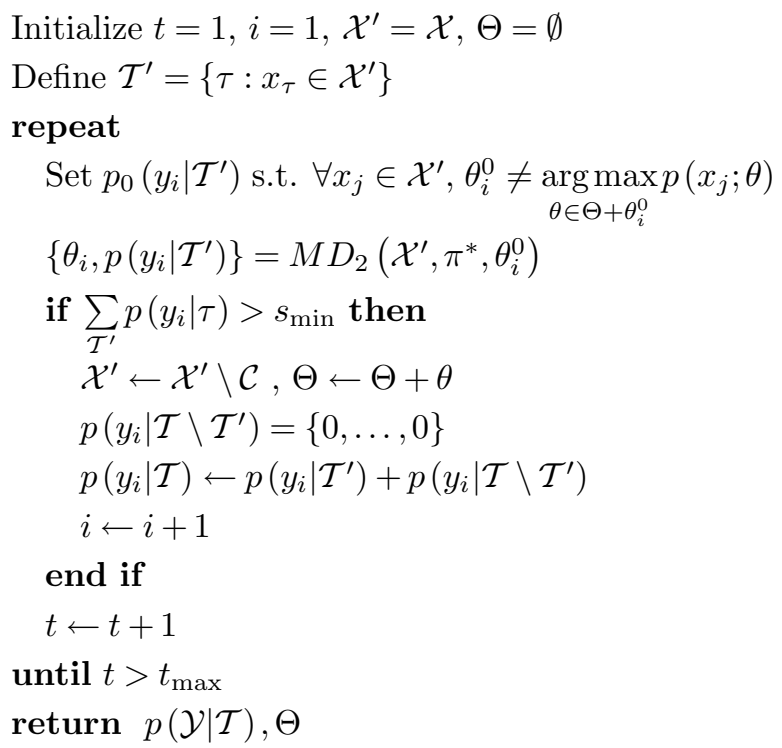

図 2 シーケンシャルマイノリティ検出 (sMD) アルゴリズム

する更新か河能となる .よって，このような $\mathcal{X}_{i}$ は $\theta_{i}$ の 統計的推定が可能な範囲て継続して縮退する.

上の解析は正規化項と典型事例のモデルの設定により 提案したコスト関数において典型事例のみで構成される 悪局所解か極めて小さいクラスタに縮退することを意味 する．次節ではこの特性を利用した閾値による擬陽性ク ラスタの判別と逐次的なクラスタ数の決定の手順を示す．

$\mathrm{MD}$ アルゴリズムに要する計算量は $p\left(y_{i} \mid \tau\right)$ と $p\left(y_{i}\right)$ の 更新に関しては $O\left(\left|\mathcal{X}_{i}\right|\right)$ である $\cdot p\left(x \mid y_{i}\right)$ の更新では $\mathcal{X}_{i}$ の統計量を求めるが, これは指数関数族を含め多くのモ デルで逐次更新可能であり, 光の場合の計算量は定数オー ダである.よって MD の一ステップの計算量は $O\left(\left|\mathcal{X}_{i}\right|\right)$ と, 暫定の異常値クラスタの要素数に線形となる.

\section{$6 \cdot 2$ 逐次マイノリティ検出 (sMD) アルゴリズム}

異常值クラスタの局所性に関する制約 $(9)$ は，同時に 複数のマイノリティクラスタが互いに重複しないことを 意味する .この前提の下では MD アルゴリズムを繰返し 用いて複数のクラスタを検出することができる .この手 順を逐次マイノリティ検出 (sMD) と呼ぶ .

$\mathrm{MD}$ アルゴリズムを関数 $M D(\cdot)$ とすると, $\mathrm{sMD}$ の手 順は次のように記述できる .

(1) $\mathcal{X}^{\prime}=\mathcal{X}, \mathcal{T}^{\prime}=\left\{\tau: x_{\tau} \in \mathcal{X}^{\prime}\right\}$ とし， $\Theta, i$ を弚れ光 れり,1に初期化する.

(2) 初期割当て $p_{0}\left(y_{i} \mid \mathcal{T}^{\prime}\right)$ を乱数等より適宜決定し， $\left\{\theta_{i}, p\left(y_{i} \mid \mathcal{T}^{\prime}\right)\right\}=M D\left(\mathcal{X}, \pi^{*}, p_{0}\left(y_{i} \mid \mathcal{T}^{\prime}\right)\right)$ を求める.

(3) $\sum_{\mathcal{T}}, p\left(y_{i} \mid \tau\right)>s_{\min }$ であるとき, $\left\{x_{\tau}: p\left(y_{i} \mid \tau\right)=1\right\}$ を集合 $\mathcal{X}^{\prime}$ から除き， $\theta_{i}$ を $\Theta$ に加える。 


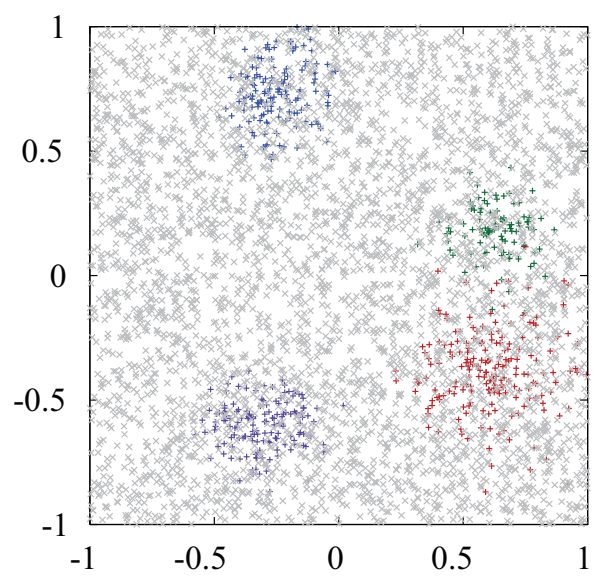

図 $3 U G^{2}$ のプロット

(4) $t<t_{\max }$ ならば $t=t+1$ とし , ステップ $(2)$ から 繰返す．乥うでなければ終了する。 ここで $t_{\max }$ は最大初期化回数を表す.

ステップ (3) では閾値 $s_{\min }$ を導入し， $\theta$ の統計的推定 が困難な小クラスタを出力から除く .このとき， $M D(\cdot)$ 内の繰返しをクラスタの大きさが $s_{\min }$ 以下になったとき 終了した場合と同じ出力が得られる . $s_{\min }$ は $\theta$ の推定に 十分な事例数を適宜選択する . この選択は生成モデルに 関する考慮に基づいて行い, データに直接は依存しない

図 2 に sMD の擬似コードを示す.sMD の特長として 混合数 $k$ に相当する入力が不要な点が挙げられる. sMD は情報量基準に基づくモデル選択のように混合数 $k$ を変 えて解を比較するのではなく, 異なる初期解から $t_{\text {max }}$ 回 試行した後混合数を $|\Theta|$ と決定する.このとき， $6 \cdot 1$ 節 に示した悪局所解に対するロバスト性から $k+1$ 番目の クラスタの存在が経験的に棄却される .

\section{7. 実 験 結 果}

\section{$7 \cdot 1$ 人エデータ}

以下では前節に示したアルゴリズムを人工的なユーク リッド空間のデータ集合を用いて検証する . 異なる中心と フルランクの分散共分散行列を持つ四つの正規分布から

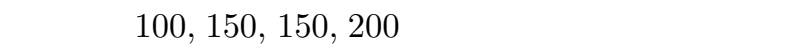
る.典型事例は二種類用意し，一方は $[-1: 1]^{d} \equiv \Omega^{d}$ 上に 一樣分布する集合とする . $d$ は次元数であり $d=2,3,5,8$ である. 事例数は $1000 \times 2^{d}$ であり，高次元でも低密度

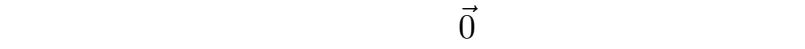
列を持つ正規分布から生成された 10,000 点とする . 実験 では特異事例と一種類の典型事例を混合して用いる. 典 型事例が一樣である方を $U G^{d}$ ，もう一方を $G G^{d}$ と記す。 $\S 1$ 視覚的検証

2 次元データのクラスタリングでは視覚的な検証か効 果的である . 以下では $U G^{2}$ と $G G^{2}$ に対する $\mathrm{sMD}$ アル ゴリズムの検出結果を視覚的に検証する. 図 3 と図 4 に
両者のプロットを示す. 典型事例 $t$ を灰色の $\times$ で表し， 特異事例 $a_{1}, \ldots, a_{4}$ を各色の+で表す．なお，典型事例 と異常値クラスタの生成モデルは $U G^{2}$ については一樣 分布と正規分布, $G G^{2}$ については共に正規分布とする $U G^{2}$ からの典型的な検出結果を图 5 に示す. 異常值ク ラスタ $c_{1}, \ldots, c_{4}$ を各色の*で表し，弚れ以外の事例 $n c$ を×で表す. 図 6 は $G G^{2}$ からの典型的な検出結果で同 樣に異常値クラスタを各色の+，弚れ以外を $\times$ で示す. いずれのデータでも特異事例の分布にほぼ近い形状で異 常値クラスタが検出された。

図 3 , 图 4 のデータに混合分布推定や密度推定に基づ くクラスタリング [Zhong 03, Hinneburg 03]や OCC 等 の他のクラスタリング手法を適用した場合 , クラスタが 典型事例の部分集合に収束する，あるいはデータ集合全 体を覆うように発散するといった現象が多く見られ，图 5 , 図 6 程度の良い結果を得ることは難しい。

\section{$\S 2$ 分類としての評価}

特異事例の検出は典型事例との二クラス分類問題とみ なすこともできる.以下では $\mathrm{sMD}$ と $\mathrm{BBC}$ アルゴリズ ム [Gupta 06] の人工データでの分類性能を比較する .

クラス分布に偏りがある場合, 分類手法の評価には適 合率 $\operatorname{Pr}$ と再現率 $R e$ が標準的に用いられる .ここでは 特異事例として生成した事例の内で異常值クラスタとし て検出したものを真陽性 $T P$, 乥れ以外を擬陰性 $F N$ と する . 同樣に , 典型事例の内で異常值クラスタとして検 出したものを擬陽性 $F P$, 乥れ以外を真陰性 $T N$ とする. 異常値クラスタの種類は区別せず 2 クラス分類問題とし て扱う.$P r$ と Re は次式で与えられる。

$$
\operatorname{Pr}=\frac{T P}{T P+F P}, R e=\frac{T P}{T P+T N}
$$

実験では $\mathrm{sMD}$ を複数のデー夕集合に適用し，適合率の 平均や分散を評価するが，光れ光れの典型事例および特 異事例が異なる分布から生成されるため，適合率のとる 值の範囲が光れらの密度比によって異なる．乥こでデータ による差異を減らすため, 相対的な適合率の指標 $P r_{\text {rel }}$ [安

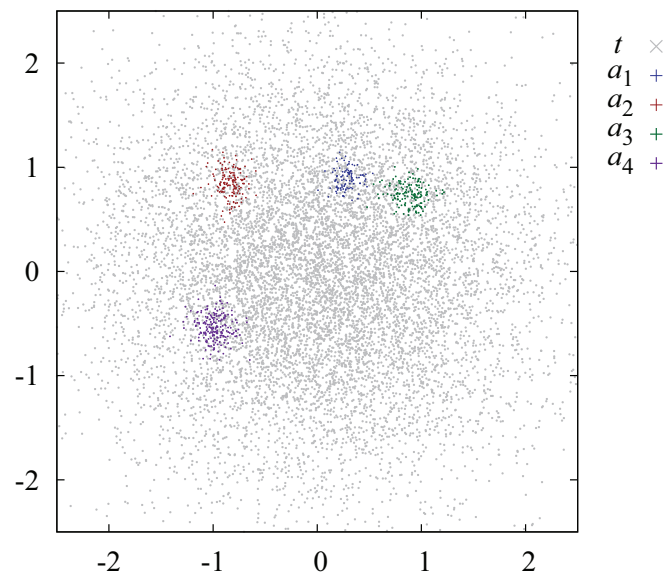

図 $4 G G^{2}$ のプロット 
表 $1 \mathrm{sMD}$ と BBC による適合率と再現率

\begin{tabular}{cccccc}
\hline \multicolumn{4}{c}{ sMD } & \multicolumn{2}{c}{$\mathrm{BBC}$} \\
\hline$d$ & $\operatorname{Pr}_{\mathrm{b}}$ & $\operatorname{Pr}_{\mathrm{rel}}$ & $\mathrm{Re}$ & $P r_{\text {rel }}$ & $\operatorname{Re}$ \\
\hline 2 & 0.22 & $1.6 \pm 0.20$ & $0.77+0.082$ & $0.49 \pm 0.52$ & $0.39 \pm 0.41$ \\
3 & 0.20 & $1.8 \pm 0.095$ & $0.63 \pm 0.15$ & $0.34 \pm 0.47$ & $0.31 \pm 0.40$ \\
5 & 0.18 & $2.3 \pm 0.89$ & $0.66 \pm 0.11$ & $0.23 \pm 0.43$ & $0.19 \pm 0.35$ \\
8 & 0.18 & $1.7 \pm 0.80$ & $0.57 \pm 0.40$ & - & - \\
\hline
\end{tabular}

藤 07] を用いる．まず，再現率が 1 となる分類を行う最 小の楕円を特異事例を生成した正規分布の固有ベクトル を基に作り，光のときの適合率を $P r_{\mathrm{b}}$ とする . 相対適合 率を $P r_{\mathrm{rel}=P r / P r_{\mathrm{b}}}$ とする. 実験では $P r_{\mathrm{b}}$ が 0.2 前後と 典型事例の密度が高いデータ集合を用いた .

[Gupta 06] は複数の BBC のアルゴリズムを示したが ， 本実験では光の中で最もロバストとされる BBC-Press を用いる. BBC-Press は局所解を回避するため，クラ スタを徐々に縮小するスケジューリングを行う．初期ク ラスタの大きさを $s_{0}=100 \times\left(2^{d}\right)$ とし , 各ステップで コスト関数 $(29)$ を最小化するような $s$ 個の事例を選択し た後， $s$ を 1 減ずる.これを繰返し，クラスタサイズが 事前に指定した值 $s_{f}=200$ に到達した後一ステップ毎 にコスト関数の収束を調べる. $\mathrm{BBC}$ はクラスタ数 $k$ を 事前に要するため $k=4$ を与える . 異なる初期値から $10 \times 2^{d-3}$ 回試行を繰返し，コスト関数が最も小さい 4 クラスタを検出結果とする . SMD も初期クラスタは同じ く $s_{0}=100 \times\left(2^{d}\right)$ とし , コスト最小の 4 クラスタを検 出結果とする.また， $i_{\max }=10 \times 2^{d-1}, s_{\min }=50$ とす る.なお， $\mathrm{SMD}, \mathrm{BBC}$ とも実験結果はこれらの值の選択 に大きく依存しない．特異事例の生成モデルは正規分布 とみなす, すなわち $\mathrm{sMD}$ の $\theta$ は平均と分散共分散行列 を, $\mathrm{BBC}$ の $D_{\phi}$ はマハラノビス距離を表すものとする . 典型事例・背景分布の生成モデルは一樣分布とする .

特異事例の正規分布を変えて 20 個の異なる $U G^{d}$ デー タを用意し， $\mathrm{sMD}, \mathrm{BBC}$ アルゴリズムを適用した．表 1 にとの際の適合率と再現率の平均と標準偏差を示す.

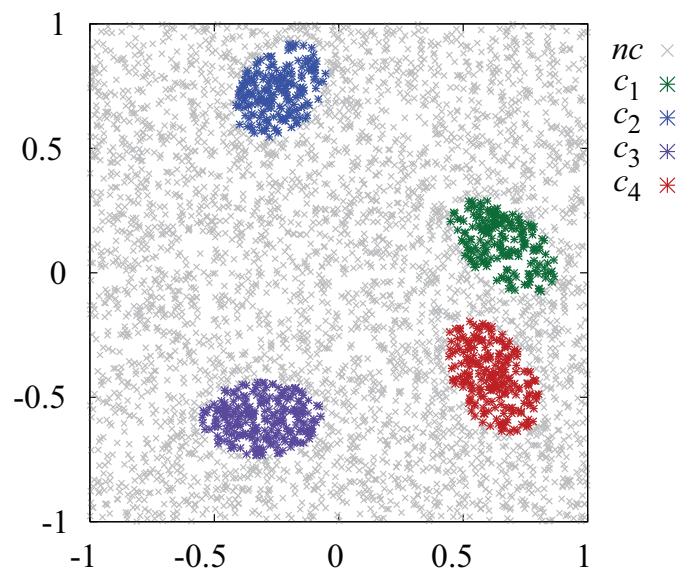

図 $5 U G^{2}$ からのマイノリティ検出
SMD は次元数が増しても安定した適合率と再現率を示 す.また，相対的な適合率が常に 1 以上となっているこ とから, $\mathrm{SMD}$ は再現率よりも適合率に偏った分類を行う と考えられる.さらに， $d=8$ のとき数十万件のデータ集 合から $0.2 \%$ 以下の特異事例集合を高い適合率で検出して いることから， sMD の規模拡張性は高いと考えられる． 一方，BBC は適合率と再現率が sMD よりも有意に低 く，分散も大きい .これは BBC がクラスタが特異事例 を含まない局所解に頻繁に収束した際に適合率と再現率 が大きく下がることからくる . BBC の収束により得られ

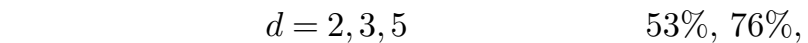
$88 \%$ が悪局所解，すなわち，全て典型事例から構成された 擬陽性クラスタであった .これに対し SMD ではクラスタ の大きさが $s_{\min }$ 末満となった場合 , クラスタ無しとみな すため悪局所解は各次元数で光れ光れ $0 \%, 0 \%, 2 \%$ であつ た . [Gupta 06] も報告しているように，OCC,BBCに は背景が疎な分布の場合も悪局所解が問題となる. SMD との差は高次でより顕著になるが， これは事例数の増大 にともない局所解の数も増加するためと考えられる .こ の結果からは, 背景分布か密な場合や次元数 $d$ が大きい 場合，BBCの適用には困難が予想される。

\section{$7 \cdot 2$ テキスト 分類問題}

ロイター 21578 コーパス ${ }^{* 1}$ は樣々な学習手法の検証に 利用されるテキストベンチマークデータである . 10,789 文書から構成され，各文書は一つ以上のトピックを持つ .

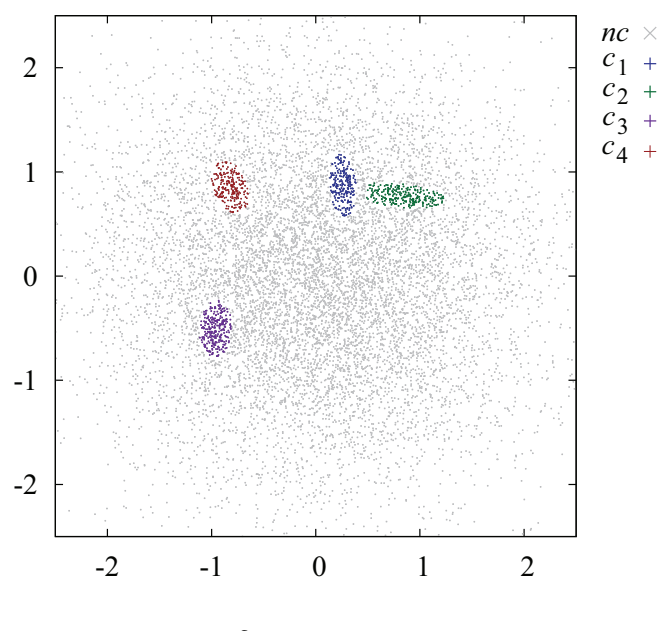

図 $6 G G^{2}$ からのマイノリティ検出 
表 2 各特異トピックにおける sMD の適合率/再現率

\begin{tabular}{ccc}
\hline topic & $k \mathrm{MD}$ & $\mathrm{BBC}$ \\
\hline oilseed & $0.91 / 0.88$ & $0.91 / 0.95$ \\
money-supply & $0.94 / 0.96$ & $0.015 / 0.016$ \\
sugar & $0.97 / 0.92$ & $0 / 0$ \\
gnp & $0.96 / 0.99$ & $0.82 / 0.88$ \\
\hline Average & $0.96 / 0.95$ & $0.44 / 0.46$ \\
\hline
\end{tabular}

実験では典型トピック $a c q$ と 4 つの特異トピック oilseed, money-supply, sugar, gnp を持つ文書を抽出し, 結合し たデータ集合 $D 1$ を用いる . 各トピックを持つ文書の数 は 2448, 192, 190, 184, 163 である.

文書の生成モデルは多くの従来研究で用いられる Bagof-words モデルとする . 文書 $\mathbf{x}$ は辞書 $\mathcal{W}=\left\{w_{i}\right\}_{i=1}^{k}$ に 含まれる単語の出現頻度 $v_{i}$ により $\mathrm{x}=\left(v_{1}, v_{2}, \ldots, v_{n}\right)$ と 表す . 辞書 $\mathcal{W}$ の選択には [Slonim 02] らの教師情報を用 いない特徵選択法を用い，文書集合 $\mathcal{X}$ との相互情報量 $I(W ; X)$ への寄与 $I\left(w_{i}\right)$ が大きい $k$ 語を $\mathcal{W}$ とする .

$$
I\left(w_{i}\right)=p\left(w_{i}\right) \sum_{\mathbf{x} \in \mathcal{X}} p\left(\mathbf{x} \mid w_{i}\right) \log \frac{p\left(\mathbf{x} \mid w_{i}\right)}{p(\mathbf{x})}
$$

以下の実験では辞書サイズ $k=200$ を用いる.

トピック $y$ に対する文書 $\mathbf{x}$ の条件付確率 $p(\mathbf{x} \mid y)$ は以 下のような多項分布とする [Nigam 00] .

$$
p(\mathbf{x} \mid y)=V ! \prod_{j=1}^{k} \frac{p\left(w_{j} \mid y\right)^{v_{j}}}{v_{j} !}
$$

ただし,$V=\sum_{i=1}^{k} v_{i}$ は $\mathbf{x}$ 内の単語の総出現回数である. 各単語の条件付確率 $p\left(w_{j} \mid y\right)$ は典型卜ピック $q$, 特異卜 ピック $\left\{r_{i}\right\}$ に対して光れ光れ次のように与える.

$$
p\left(w_{j} \mid q\right)=\frac{1+\sum_{\mathbf{x} \in \mathcal{X}} v_{j}}{k+\sum_{i=1}^{k} \sum_{\mathbf{x} \in \mathcal{X}} v_{j}}, p\left(w_{j} \mid r\right)=\frac{1+\sum_{\mathbf{x} \in \mathcal{Z}_{i}} v_{j}}{k+\sum_{i=1}^{k} \sum_{\mathbf{x} \in \mathcal{Z}_{i}} v_{j}}
$$

ただし， $\mathcal{Z}_{i}$ は $y=r_{i}$ となる $\mathcal{X}$ の部分集合である.

sMD と BBC-Press を以下の設定で $D 1$ に適用する. $\mathrm{BBC}$ の距離関数は文書の多項分布間の $\mathrm{KL}$ ダイバージェ ンスとし, 初期クラスタはランダムに選択した 1 文書から 最も近い 800 文書とする . 収束を調べる閾値は $s_{f}=200$ とし， $k=4$ は所与とする. 異なる初期解から 5 回試行 し, コスト関数が最も小さい 4 クラスタを検出結果とす る. $\mathrm{sMD}$ は $t_{\max }=20$ とし, 最小のコストを与えるク ラスタ 4 つを検出結果とする.クラスタの初期化方法は BBC と同樣とする . 検出したクラスタについて, 光の要 素の内 $a c q$ を除いて最も多いトピックをクラスタのラベ ルとみなし適合率と再現率を計算する。

表 2 に二つのアルゴリズムのトピック毎の適合率と再 現率を示す. SMD は全てのトピックで教師付学習手法に
匹敵する高い值を示した .一方, BBC は相当回数の試行 が典型トピックの部分集合に収束するため, 相対適合率が sMD よりも有意に低く，再現率も大きく下がる．BBCPress は $s_{f}$ に到達してからすぐに収束するため, 光の適 合率は $s_{f}$ の選択にも依存する.$s_{f}$ が異常値クラスタの 大きさに近いとき比較的良い適合率を得やすいが，この 值を事前に知るのは困難である [ [Gupta 05] は OCC の $s_{f}$ 值を変えて試行を繰返す手法を提案したが，光の場合 には試行回数が非常に大きくなるという問題がある .

$\mathrm{BBC}, \mathrm{sMD}$ 共にデータの大部分が典型事例であるとい う前提を用いており教師無し学習手法との比較には注意 を要するが，本実験の結果からは $\mathrm{sMD}$ が事例数が少な く，教師情報を得難いクラスの検出に有効と考えられる．

\section{8.お おりに}

本稿では情報理論的枠組みを基に異常値クラスタの検 出問題であるマイノリティクラスタリングの定式化を示 し，外机值検出や一クラスクラスタリング等の従来手法 との関連を議論した .さらに, 複数のクラスタを逐次的 に検出するアルゴリズムを示し , 教師情報の無い分類問 題において兴の性能を実験的に検証した .

マイノリティクラスタリングでは正規化項と典型事例 のモデルの利用により，弚の分布に近い異常值クラスタ は記述コストが見合わず縮退する $.7 \cdot 1$ 節の実験における 適合率・再現率および悪局所回数への収束率からも $\mathrm{sMD}$ が BBCよりも擬㪚性検出を抑え，悪局所解に対して口 バストであることが分かる $\mathrm{OCC}, \mathrm{BBC}$ はマイノリティ 検出の特殊ケースとみなせるが, クラスタの大きさを指 定するため記述コストに関する正規化の効果は失われる． また , 次数の増大にともない光の差はより顕著になるが， これはデータの規模によって悪局所解の数か増加するた めと考えられる.sMDは擬陽性クラスタの少なさを利用 してクラスタの個数を一定回数の試行後に経験的に決定 するが，これはクラスタ数 $k$ を事前に決定することか難 しい場合に効果的と考えられる。

$\mathrm{sMD}$ およびBBC のアルゴリズムでは, 典型事例のパ ラメータを更新しないため全スキャンの繰返しが不要で ある.これは各クラスタのパラメータ決定の全体に与え る影響を簡略化したものといえる．全クラスタを同時に 評価する $k$ 平均法や最尤混合推定等と比較するとこのよ うな処理は並列性が高く，空間計算量も抑えられるため 規模拡張性が高いといえる.

マイノリティクラスタリングの入力 $p(T) p(X \mid T)$ は $\mathcal{X}$ からハンパラメトリックに推定される分布といえるが， 更新式(32)-(34) には炎の要素である $p(x \mid \tau)$ は直接現れ ない. 弚の結果，手法自体は $p(x \mid y)$ のモデルのみを考え るパラメトリックなものとなる点は興味深い，また，又 イノリティクラスタリングの定式化では，異常值クラス タを局所的に分布するものとみなすが, 生成モデルとし 


\section{て分散の小さい正規分布や多項分布などの指数関数族を}

扱う場合，このような前提は妥当と考えられる.

本稿の実験で用いた $\beta$ の值は擬陽性クラスタの検出を

避けるという目的に適したものであった .ただし， $\beta$ は 正規化項の重みであり，真陽性クラスタにおける適合率 と再現率にも影響するため実用的な值の選択はデータの 種類と用途に依存する．応用毎の要請に対しては本実験 で用いた值を基準として実験的に調整するのが妥当であ る. $\beta$ の值が具体的に擬陽性クラスタの検出率や適合率. 再現率に与える影響に関してさらに検討が必要である．

マイノリティクラスタリングはデータ集合中の特異事 例を孤立した事象ではなくクラスタとして抽出し，光の 統計量を利用できる手法であり，今後の課題としてこの 特徵を生かした知識発見の応用に取組む。

\section{$\diamond$ 参 考 文 献 $\diamond$}

[Ando 06] Ando, S. and Suzuki, E.: An Information Theoretic Approach to Detection of Minority Subsets in Database, in ICDM '06: Procs. of the Sixth International Conference on Data Mining, pp. 11-20, Washington, DC, USA (2006), IEEE Computer Society

[安藤 07] 安藤 晋, 佐久間 淳, 鈴木 英之進, 小林 重信: 情報理論 的枠組に基づくマイノリティ集合の検出, 人工知能学会論文誌, Vol. 22, No. 3, pp. 311-321 (2007)

[Banerjee 04] Banerjee, A., Dhillon, I. S., Ghosh, J., and Merugu, S.: An Information Theoretic Analysis of Maximum Likelihood Mixture Estimation for Exponential Families., in Procs. of the 21st International Conference on $\mathrm{Ma}$ chine Learning, pp. 182-190, ACM (2004)

[Banerjee 05] Banerjee, A., Merugu, S., Dhillon, I. S., and Ghosh, J.: Clustering with Bregman Divergences, J. Mach. Learn. Res., Vol. 6, pp. 1705-1749 (2005)

[Chechik 05] Chechik, G., Globerson, A., Tishby, N., and Weiss, Y.: Information Bottleneck for Gaussian Variables, J. Mach. Learn. Res., Vol. 6, pp. 165-188 (2005)

[Crammer 04] Crammer, K. and Chechik, G.: A Needle in a Haystack: Local One-class Optimization, in Procs. of the 21st International Conference on Machine learning, pp. 2633, New York, NY, USA (2004), ACM Press

[Dhillon 03] Dhillon, I. S., Mallela, S., and Kumar, R.: A Divisive Information-Theoretic Feature Clustering Algorithm for Text Classification., Journal of Machine Learning Research, Vol. 3, pp. 1265-1287 (2003)

[Elidan 05] Elidan, G. and Friedman, N.: Learning Hidden Variable Networks: The Information Bottleneck Approach, J. Mach. Learn. Res., Vol. 6, pp. 81-127 (2005)

[Gao 07] Gao, Y., Gu, S., Li, J., and Liao, Z.: The Multi-view Information Bottleneck Clustering, in Advances in Databases: Concepts, Systems and Applications, Vol. 4443 of Lecture Notes in Computer Science, pp. 912-917, Springer Verlag, Berlin (2007)

[Gordon 03] Gordon, S., Greenspan, H., and Goldberger, J.: Applying the Information Bottleneck Principle to Unsupervised Clustering of Discrete and Continuous Image Representations, in Procs. of Ninth IEEE International Conference on Computer Vision (ICCV), Vol. 1, pp. 370-377, Los Alamitos, CA, USA (2003), IEEE Computer Society

[Gupta 05] Gupta, G. and Ghosh, J.: Robust One-class Clustering using Hybrid Global and Local Search, in Procs. of the 22nd International Conference on Machine Learning, pp. 273-280, New York, NY, USA (2005), ACM Press

[Gupta 06] Gupta, G. and Ghosh, J.: Bregman Bubble Clustering: A Robust, Scalable Framework for Locating Multi- ple, Dense Regions in Data, in ICDM '06: Procs. of the Sixth International Conference on Data Mining, pp. 232243, Washington, DC, USA (2006), IEEE Computer Society

[Hinneburg 03] Hinneburg, A. and Keim, D. A.: A General Approach to Clustering in Large Databases with Noise, Knowl. Inf. Syst., Vol. 5, No. 4, pp. 387-415 (2003)

[Hodge 04] Hodge, V. and Austin, J.: A Survey of Outlier Detection Methodologies, Artif. Intell. Rev., Vol. 22, No. 2, pp. $85-126$ (2004)

[Hsu 06] Hsu, W. H., Kennedy, L. S., and Chang, S.-F.: Video Search Reranking via Information Bottleneck Principle, in MULTIMEDIA '06: Procs. of the 14th annual ACM International Conference on Multimedia, pp. 35-44, New York, NY, USA (2006), ACM

[Kearns 99] Kearns, M. J., Mansour, Y., and Ng, A. Y.: An Information-theoretic Analysis of Hard and Soft Assignment Methods for Clustering, in Learning in Graphical Models, pp. 495-520, MIT Press, Cambridge, MA, USA (1999)

[Nigam 00] Nigam, K., McCallum, A., Thrun, S., and Mitchell, T. M.: Text Classification from Labeled and Unlabeled Documents using EM., Machine Learning, Vol. 39, No. $2 / 3$, pp. 103-134 (2000)

[Roth 06] Roth, V.: Kernel Fisher Discriminants for Outlier Detection, Neural Comput., Vol. 18, No. 4, pp. 942-960 (2006)

[Schölkopf 01] Schölkopf, B., Platt, J. C., Shawe-Taylor, J., Smola, A. J., and Williamson, R. C.: Estimating the Support of a High-Dimensional Distribution., Neural Computation, Vol. 13, No. 7, pp. 1443-1471 (2001)

[Slonim 02] Slonim, N., Friedman, N., and Tishby, N.: Unsupervised Document Classification using Sequential Information Maximization, in SIGIR '02: Procs. of the 25th annual International ACM SIGIR Conference on Research and Development in Information Retrieval, pp. 129-136, New York, NY, USA (2002), ACM Press

[Slonim 06] Slonim, N., Friedman, N., and Tishby, N.: Multivariate Information Bottleneck., Neural Computation, Vol. 18, No. 8, pp. 1739-1789 (2006)

[Tishby 00] Tishby, N., Pereira, F. C., and Bialek, W.: The Information Bottleneck Method, in Computing Research Repository(CoRR), physics/0004057 (2000)

[Zhong 03] Zhong, S. and Ghosh, J.: A unified framework for model-based clustering, J. Mach. Learn. Res., Vol. 4, pp. 1001-1037 (2003)

〔担当委員: 熟尾 隆〕

2008 年 2 月 13 日 受理

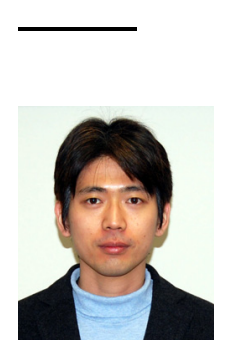

者 紹 介

\section{安藤 晋(正会員)}

1999 年東京大学工学部電子情報工学科卒業. 2004 年同 大学大学院工学系研究科電子工学専攻博士課程修了. 博士 (工学). 東京工業大学大学院総合理工学研究科特別研究員, 横浜国立大学工学研究院助手等を経て 2008 年 4 月より群 馬大学大学院工学系研究科情報工学専攻助教. 現在に至る. 進化的計算手法, データマイニングの研究に従事. IEEE, $\mathrm{ACM}$, 情報処理学会各会員.

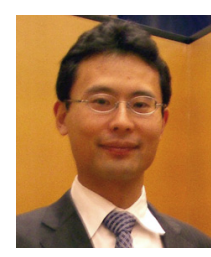

鈴木 英之進(正会員)

1988 年 3 月東京大学工学部航空学科卒業. 1993 年 3 月 同大学院工学系研究科航空学専攻博士課程修了, 博士 (工 学). 東京工業大学助手, 横浜国立大学講師, 助教授を経 て 2006 年 4 月より九州大学大学院システム情報科学研究 院教授、現在に至る。データマイニング, 機械学習, 知識 工学に関する研究に従事。情報処理学会, AAAI, ACM, IEEE 各会員. 